\title{
Opportunities and Challenges of Nurses after Upgradation of Class 2 Status
}

\author{
Akter $M^{1}$, Begum $M R^{2}$, Begum $R^{3}$, Sultana $N^{4}$
}

\begin{abstract}
Nurse's job facilities and challenges have emerged as a burning issue in health care delivery system in Bangladesh. This descriptive cross sectional study with a mixed quantitative and qualitative design aimed to explore the opportunities and challenges of nurses after upgradation of class 2 status. The study was carried out in two specialized public hospitals for one year duration among purposively selected 144 nurses with a semi structured interview administered questionnaire In depth interview and focus group discussion (FGD) were conducted among selected personnel. The study revealed that the mean age of nurses was $42.3( \pm 6.3)$ years, majority $(86.1 \%)$ were female, most of them $(79.1 \%)$ were senior staff nurse with 16.8 years mean working experience. The study explored the opportunities of nurses after upgradation of class 2 status like increased responsibilities and honor in working place, promotional opportunities mentioned by majority of respondents. On the other hand, the challenges were noted as not changing the physicians attitude, not changing the working environment, limited scope for utilization of professional skill, not having job security mentioned by majority of respondents. The study also found that most of the nurses $(90.3 \%)$ were satisfied after upgradation, but a large portion were not satisfied regarding fringe benefits and current salary structure. From FGD and in depth interview some suggestions come forward for nursing profession empowerment like good salary package, medical incentive, residence and training facilities etc. Few opportunities increased in upgradation of nurses in class 2 status, however nurses were depriving from many of their facilities, which indicated that $2^{\text {nd }}$ class status was partially implemented in professionally, socially and culturally.
\end{abstract}

\section{Keywords : Opportunities, Challenges, Nurse, Upgradation.}

1. Senior Staff Nurse, National Institute of Neuroscience \& Hospital, Dhaka.

2. Staff Nurse, National Institute of Traumatology and Orthopaedic Rehabilitation, Dhaka.

3. Staff Nurse, Dhaka Medical College and Hospital, Dhaka.

4. Assistant professor, Department of Dental Anatomy, Mandy Dental College \& Hospital, Dhaka.

Address of correspondence: Dr. Nihar Sultana, Assistant professor, Department of Dental Anatomy, Mandy Dental College \& Hospital, Dhaka. email: nihard40@ gmail.com

\section{Introduction}

Nursing is a noble profession that can be both rewarding and challenging at the same time. Nurses play a very important role in the healthcare industry, as well as they save and improve lives as front line members of the health care delivery team. They provide care and, if needed, alert other health care professionals to assist. As because nurses are present in the hospitals for 24 hours by shifting duty, 7 days in a week, observing,

Bangladesh Journal of Medical Education 2022; 13(1); Akter et al., publisher and licensee Association for Medical Education. This is an Open Access article which permits unrestricted non-commercial use, provided the original work is properly cited. 
intervening, and reporting changes in patient condition. ${ }^{\mathbf{1}}$ They are hands-on caregivers that make major healthcare contributions by assessing, planning, and evaluating patient care needs; delivering medications, assuring patient's comfort and advocating for their needs. ${ }^{2}$ Like many countries in the world, Bangladesh is facing an acute crisis of skilled nurses. Although nurses are the essential part of healthcare system, there are very little initiatives to promote this noble profession. In Bangladesh nursing is considered as a second segmental job. That is why the work value and social recognition does not encourage the brilliant boys and girls to join the profession. It creates an ill impression and contributes as one of the major causes of shortage. Bangladesh is one of a few countries in the world that has more medical doctors than nurses: about three medical doctors to one nurse. ${ }^{3}$ Furthermore, due to the shortage of nurses and a challenging working environment (e.g. lack of nursing equipment and effective nursing management system), with few exceptions the quality of nursing care has been called in to question. To address these challenges, the Government of Bangladesh is increasing efforts to raise the image; improve the quality of services and education; and meet the shortage of nurses and midwives. One of the most important initiative taken by Bangladesh Govt. for the empowerment of nursing profession is upgradation of nurses from $3^{\text {rd }}$ class to $2^{\text {nd }}$ class status. On 06.04.2011 Ministry of health and family planning (MOHFW-2011) declared a upgradation of all the diploma nurses (senior staff nurse, staff nurse, public health nurse and nurses) from $3^{\text {rd }}$ class (salary scale tk.6400-14255) to $2^{\text {nd }}$ class(salary scale tk.8000-16540) with financial benefits ordered by The president of Bangladesh and signed by assistant Secretary Sahanunnessa. Establishment ministry has agreed the proposal on 16.1.2011, file no 05.159.015.4500.024.2011-22 and finance ministry has agreed the proposal on 13.2.2011 file no. 07.156.015.45.02.02.2011-70. ${ }^{4}$ After the upgradation notice there have lot of changed in nursing society in Bangladesh. For these reason nurses have gained lot of opportunities and challenges. Present study aimed to explore the opportunities and challenges of nurses after upgradation from class 3 to class 2 status.

\section{Materials and methods :}

A descriptive type of cross sectional study (mixed method) conducted for the duration of one year with the aim to explore the opportunities and challenges of nurses after upgradation from class 3 to class 2 status. Through purposive sampling technique 144 nurses were selected according to the selection criteria of the study from two specialized public hospitals in Dhaka

Bangladesh Journal of Medical Education 2022; 13(1); Akter et al., publisher and licensee Association for Medical Education. This is an Open Access article which permits unrestricted non-commercial use, provided the original work is properly cited. 
named National Institute of Traumatology and Orthopedic Rehabilitation (NITOR) and National Institute Cardiovascular Disease (NICVD). The selection criteria includes the nurses who had at least 2 years of working experience, who involved in direct patient care and who passed at least diploma in nursing. In depth interview and focus group discussion (FGD) were conducted among the selected personnel in the study hospitals. An interview administered semi structured questionnaire and FGD format prepared using variables using variables according to the specific objectives of the study and made simple, easily understandable to the respondents.
Ethical clearance was obtained from the Institutional Review Board (IRB) of National Institute of Preventive and social Medicine (NIPSOM). Prior to the study, a written permission was taken from the Director of the hospital and verbal consent was taken from the respondents to conduct the study. Finally after checking and editing, data were analyzed by using SPSS software version 21 based on the study objectives and presented by tables and figure. Data derived from FGD and in depth interview were scrutinized immediately after interview and summarized in a narrative. Confidentiality and anonymity of the respondents were maintained strictly.

Table 1: Socio demographic characteristics of the nurses

\begin{tabular}{|l|l|l|}
\hline \multicolumn{2}{|l|}{ Socio demographic characteristics } & $\mathbf{N}(\%)$ \\
\hline \multirow{3}{*}{ Age group (in years) } & $30-39$ & $55(38.2)$ \\
\cline { 2 - 3 } & $40-49$ & $66(45.8)$ \\
\cline { 2 - 3 } & $\geq 50$ & $23(16.0)$ \\
\cline { 2 - 3 } & Mean $( \pm \mathrm{SD}): 42.4( \pm 6.3)$, Range $: 30-60$ years \\
\hline \multirow{3}{*}{ Sex } & Male & $20(13.9)$ \\
\cline { 2 - 3 } & Female & $124(86.1)$ \\
\hline Marital status & Married & $9(6.2)$ \\
\cline { 2 - 3 } & Unmarried & \\
\hline
\end{tabular}

Bangladesh Journal of Medical Education 2022; 13(1); Akter et al., publisher and licensee Association for Medical Education. This is an Open Access article which permits unrestricted non-commercial use, provided the original work is properly cited. 
Table 2: Occupational characteristics of the nurses

\begin{tabular}{|c|c|c|}
\hline \multicolumn{2}{|c}{ Occupational characteristics } & $\mathbf{N}(\%)$ \\
\hline \multirow{2}{*}{$\begin{array}{c}\text { Educational } \\
\text { qualification }\end{array}$} & Diploma in nursing & $110(76.4)$ \\
\cline { 2 - 3 } & BSc / BSc PHN & $26(18.0)$ \\
\cline { 2 - 3 } & MSc /MPH & $8(5.6)$ \\
\hline \multirow{2}{*}{$\begin{array}{c}\text { Designation } \\
\text { experience } \\
\text { (in years) }\end{array}$} & Senior staff nurse & $114(79.2)$ \\
\cline { 2 - 3 } & Staff nurse & $30(20.8)$ \\
\cline { 2 - 3 } & $11-20$ & $16(11.1)$ \\
\cline { 2 - 3 } & $21-30$ & $53(52.1)$ \\
\cline { 2 - 3 } & $\geq 31$ & 1 \\
\cline { 2 - 3 } & Mean $( \pm$ SD) $: 16.8 \pm(7.8)$ years, Range : 4 - 32 years \\
\hline
\end{tabular}

Table 3 : Opportunities of nurses after upgradation of Class 2 status

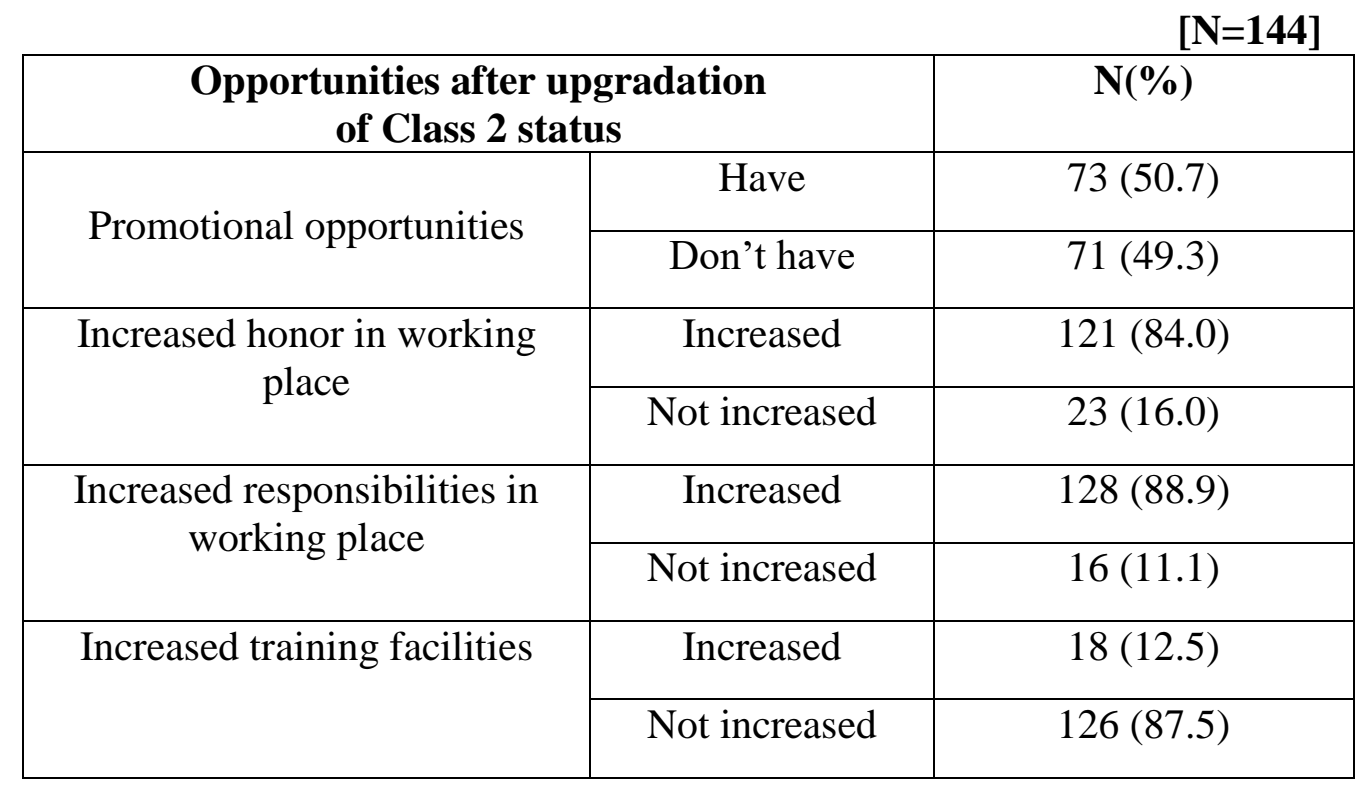

Bangladesh Journal of Medical Education 2022; 13(1); Akter et al., publisher and licensee Association for Medical Education. This is an Open Access article which permits unrestricted non-commercial use, provided the original work is properly cited. 
Table 4 : Challenges of nurses after upgradation of Class 2 status

\begin{tabular}{|c|c|c|}
\hline \multicolumn{2}{|c}{$\begin{array}{c}\text { Challenges after upgradation } \\
\text { of Class 2 status }\end{array}$} & $\mathbf{N}(\mathbf{\%})$ \\
\hline \multirow{2}{*}{ Physicians attitude } & Changed & $18(12.5)$ \\
\cline { 2 - 3 } & Not changed & $126(87.5)$ \\
\hline Security of job & Have & $60(41.7)$ \\
\cline { 2 - 3 } & Don't have & $80(58.3)$ \\
\hline $\begin{array}{c}\text { Utilization of } \\
\text { professional skill }\end{array}$ & Have scope & $31(21.5)$ \\
\cline { 2 - 3 } & Don't have scope & $113(78.5)$ \\
\hline $\begin{array}{c}\text { Working pattern or } \\
\text { environment }\end{array}$ & Changed & $13(9.0)$ \\
\cline { 2 - 3 } & Not changed & $131(91.0)$ \\
\hline
\end{tabular}

Figure 1 : Satisfaction of nurses after upgradation of class 2 status

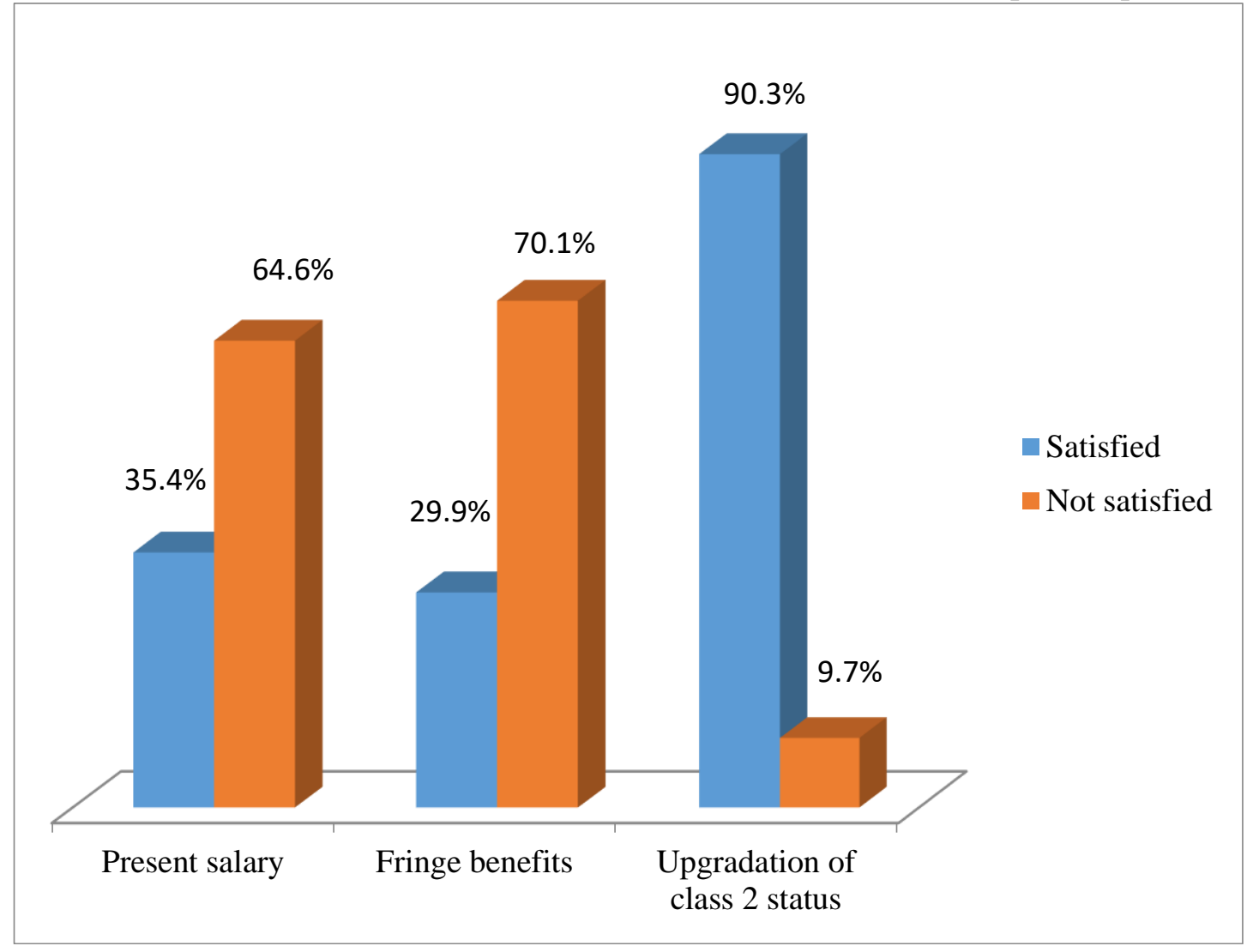

Bangladesh Journal of Medical Education 2022; 13(1); Akter et al., publisher and licensee Association for Medical Education. This is an Open Access article which permits unrestricted non-commercial use, provided the original work is properly cited. 


\section{Discussion}

Present study tried to explore the opportunities and challenges of nurses after upgradation of class 2 status. The socio demographic picture of the study population revealed that the mean age of nurses $42.3( \pm 6.3)$ years, almost half $(45.8 \%)$ were in 40 - 49 years age group, majority $(86.1 \%)$ were female and most of them $(93.8 \%)$ were married (Table 1$)$. The mean age of the nurses was almost similar with the study conducted by Latif. ${ }^{5}$ The age distribution found more or less similar in different age group with the study conducted by Rozario et al., ${ }^{6}$ also the marital status found close to present study. It is universal reality that nursing is a female profession worldwide. In Bangladesh, there are few options for male person to enter in nursing profession. According to nursing admission policy in Bangladesh, only $10 \%$ male students are able to access to the entry level nursing education program to be a nurse. Regarding occupational characteristics present study showed that majority $(79.1 \%)$ were senior staff nurse, the mean working experience was 16.8 years, more than half $(52.1 \%)$ nurses working experience was 11-20 years (Table 2). So it can be said that selection of sample was appropriate for getting relevant information to obtain the study objectives. The opportunities of nurses after upgradation of class 2 status mentioned as promotional opportunities by $50.7 \%$, increased honor in working place by $84.0 \%$, increased responsibilities by $88.9 \%$, increased training facilities by $12.5 \%$ (Table 3). On the other hand, majority $(87.5 \%)$ think they faced the challenges like not changing the physicians attitude; other challenges noted as not changing the working environment, limited scope for utilization of professional skill, not having job security by $91.0 \%, 78.5 \%, 58.3 \%$ respectively(Table 4). This situation can be explained as combine working environment. According to American Nurses Association (ANA) and Working Environment of Nurses in District Hospitals - the working environment plays a large role in the ability to provide quality care. ${ }^{7}$ The environments of working place are critically important. The study result also showed that most of the nurses $(90.3 \%)$ were satisfied after upgradation, but a large portion $70.1 \%, 64.6 \%$ were not satisfied regarding fringe benefits and current salary structure (Figure 1).

From FGD and in depth interview it was summarized that all of them had better feeling after upgradation from class 3 to class 2 status, but they claimed that after upgradation they write as nursing officer without any power. Working encircles and responsibilities were same as before. Most of them pointed unsatisfactory working environment, disappointed regarding salary structure and behavior of clark in the hospital. They noticed that before

Bangladesh Journal of Medical Education 2022; 13(1); Akter et al., publisher and licensee Association for Medical Education. This is an Open Access article which permits unrestricted non-commercial use, provided the original work is properly cited. 
upgradation they got tiffin allowance, but now they are not getting that facility, so they are economically depriving after upgradation. Rather they are not getting any night or risk allowance. Though after upgradation their salary increased, but they are depriving from these facilities. Because of the scarcity of extra post, they have very limited promotional opportunity and also training opportunities are not sufficient. Some suggestions noted for the empowerment of nursing profession like allowance for night duty, tiffin allowance, good salary package, medical incentive, residence facility, training facility, separate university for nursing, increase nursing staff, ensure proper and specific distribution of nursing staff, highly qualified, skilled, post graduate nurses should be recognized by promotion.

\section{Conclusion}

On the above discussion, it is clear that declaration of $2^{\text {nd }}$ class is just an administrative order. It is a general feeling of nurses that they were satisfied in sense of declaration of their status. In relation to $2^{\text {nd }}$ class status, a few opportunities were increased. However nurses were facing a lot of challenges and they were deprived from their many facilities and right adherence to $2^{\text {nd }}$ class status. That mean $2^{\text {nd }}$ class status was partially implemented in professionally, socially, and culturally. The findings of the study can be use to help the health care professionals, health administrators, health policy makers to enhance nursing services for provide quality patient care. Lastly, if appropriate measures can be taken properly, nurses job satisfaction can be significantly improved which can leads to provide quality care that ultimately leads to the good achievement in nursing profession.

\section{References :}

1. Burhans LM. What is good nursing care? The lived meaning of quality nursing care for practicing nurses. The Faculty of the college of nursing, East Carolina University, USA. May 2008

2. Burhans LM, Alligood MR. Quality nursing care in the words of nurses, journal of advanced nursing, East Carolina University College of Nursing, Greenville, NC, USA. March 2010

3. DNS , 2011, present scenario of Nursing in Bangladesh: Nursing services (; http://www.dns.gov.bd/).

4. MOHFW-2011, declared a upgradation of all the diploma nurses from $3^{\text {rd }}$ class to $2^{\text {nd }}$ class, 6 April.

5. Latif, A, 2010, Relationship between organizational climate and nurse's job satisfaction in Bangladesh

6. Rozario M D, Adhikary H, Gazi HR, Begum D. Nurses' Roles in Patient Care in Tertiary Level Hospitals in Bangladesh Bangladesh Med Res Counc Bull 2018; 44: 138-144

DOI : https://doi.o $\mathrm{rg} / 10$ .3329/bmrcb.v44i3.39937

7. Hasan, F, Sultana R, Nahar, L, 2005, Working Environment of Nurses in District Hospital.

Bangladesh Journal of Medical Education 2022; 13(1); Akter et al., publisher and licensee Association for Medical Education. This is an Open Access article which permits unrestricted non-commercial use, provided the original work is properly cited. 